\title{
HUBUNGAN ASUPAN LEMAK, ASUPAN GARAM DAN STATUS GIZI DENGAN TEKANAN DARAH PENDERITA HIPERTENSI DI UPT. PUSKESMAS SINGKAWANG TIMUR I
}

\section{THE RELATIONSHIP OF FAT INTAKE, SALT INTAKE AND NUTRITIONAL STATUS WITH THE BLOOD PRESSURE OF PEOPLE WITH HYPERTENSION IN UPT. PUSKESMAS SINGKAWANG TIMUR I}

\author{
Yulia Farahdini ${ }^{1)}$ \\ 1)Akademi Gizi Sinka Dharma Madani, Jalan Latsitarda, Singkawang Selatan \\ *Email : yulia87farahdini@gmail.com
}

Submit 24 Juni 2020, Revisi 29 Oktober 2020, Terbit 31 Desember 2020

\begin{abstract}
Hypertension is often called a silent killer. This study aimed to analyse the relationship of fat intake, salt intake and nutritional status with the blood pressure of people with hypertension in UPT. Puskesmas Singkawang Timur l. The data were collected by accidental sampling with data measuring instruments by using a questionnaire and food recall's form. The results of the bivariate analysis showed that the respondents with high fat intake had high blood pressure were 57 people (78.1\%); the respondents with low salt intake had high blood pressure were 33 people (54.8\%); the respondents with normal nutritional status had high blood pressure were 56 people (76.72\%), and the respondents with nutritional status obesity had high blood pressure were 17 people (23.28\%). The research found out that there was not any correlation between fat intake and blood pressure; and between nutritional status and hypertensive patient's blood pressure. But, there was a positive correlation-between salt intake and blood pressure in the UPT. Puskesmas Singkawang Timur I.
\end{abstract}

Keywords: Fat, Salt, Hypertension

\begin{abstract}
ABSTRAK
Hipertensi sering disebut sebagai silent killer. Penelitian ini bertujuan untuk mengetahui hubungan antara asupan lemak, asupan garam dan status gizi terhadap tekanan darah pada penderita hipertensi di UPT. Puskesmas Singkawang Timur I. Sampel diambil berdasarkan accidental sampling dengan alat pengumpul data berupa kuesioner dan formulir food fecal. Hasil analisis bivariat menunjukkan bahwa responden dengan asupan lemak tinggi dengan tekanan darah tinggi sebanyak 57 orang $(78.1 \%)$; responden dengan asupan garam tinggi memiliki tekanan darah tinggi sebanyak 40 orang $(54.8 \%)$; responden dengan status gizi normal memiliki tekanan darah tinggi sebanyak 56 orang $(76.72 \%)$; dan responden dengan status gizi obesitas memiliki tekanan darah tinggi sebanyak 17 orang $(23.28 \%)$. Hasil penelitian menunjukkan bahwa tidak ada hubungan antara asupan lemak dengan tekanan darah dan juga tidak ada hubungan antara status gizi dengan tekanan darah pada pasien hipertensi. Namun, terdapat hubungan antara asupan garam dengan tekanan darah pada pasien di UPT. Puskesmas Singkawang Timur I.
\end{abstract}

Kata Kunci: Lemak, Garam, Hipertensi 


\section{PENDAHULUAN}

Hipertensi merupakan penyakit degeneratif yang menjadi masalah serius saat ini. Hipertensi di kategorikan sebagai the silent killer karena penderita tidak mengetahui dirinya mengidap hipertensi atau tidak mengetahui sebelum memeriksakan tekanan darahnya. Insiden hipertensi meningkat seiring bertambahnya usia. Menurut WHO, seseorang dikatakan mengalami hipertensi jika mengalami peningkatan tekanan darah diatas 140/90 mmHg (Nuraini, 2012). Bahaya hipertensi yang tidak terkendali dapat menimbulkan komplikasi yang berbahaya, seperti jantung koroner, stroke, gagal ginjal, dan gangguan penglihatan. Kematian akibat hipertensi menduduki peringkat atas dari pada penyebab-penyebab lainnya (Artiyaningrum, 2016).

Konsumsi tinggi lemak dapat menyebabkan tekanan darah meningkat. Konsumsi lemak kadar kolestrol dalam darah terutama kolestrol LDL dan akan tertimbun dalam tubuh. Timbunan lemak yang disebabkan oleh kolestrol akan menempel pada pembuluh darah yang lama-kelamaan akan terbentuk plaque yang dapat menyebabkan penyumbatan pembuluh darah. Pembuluh darah yang terkena ateroklerosis akan berkurang elastisitasnya, dan aliran darahnya ke seluruh tubuh akan terganggu serta dapat memicu meningkatannya volume darah dan tekanan darah. Meningkatnya tekanan darah tersebut mengakibatkan terjadinya hipertensi (Ismuningsih, 2013).

Natrium paling banyak terdapat didalam cairan ekstra sel, seperti cairan dalam pembuluh darah dan cairan didalam jaringan di antara sel-sel. Garam dapur mengandung natrium yang dibutuhkan tubuh untuk menjalankan fungsi tubuh. Peningkatan asupan garam dapat mempengaruhi peningkatan tekanan darah yang mengakibatkan penurunan fungsi tubuh (Yulistina, 2017).

Mengukur tekanan darah perlu dilakukan secara rutin baik secara langsung maupun tidak langsung. Pengukuran tekanan darah secara langsung dapat dilakukan dengan memasukkan kateter kedalam arteri. Pengukuran dengan metode ini akan memberikan hasil yang akurat, namun dapat menimbulkan masalah lain. Oleh karena itu, sekarang pengukuran tekanan darah dilakukan secara tidak langsung dengan menggunakan sphygmomanometer dan stetoskop (Ismuningsih, 2013).

Status gizi menjadi salah satu faktor yang dapat mempengaruhi tekanan darah. Seseorang yang memiliki berat badan berlebih cenderung mempunyai tekanan darah tinggi daripada mereka yang kurus. Hal ini disebabkan semakin berat massa tubuh (IMT) seseorang maka semakin banyak darah yang dibutuhkan untuk menyampaikan oksigen dan zat gizi ke dalam jaringan tubuh sehingga volume darah dipembuluh darah bertambah yang memberikan tekanan yang lebih besar pada dinding pembuluh darah arteri yang mengakibatkan tekanan darah tinggi. Pada status gizi obesitas, ada penurunan tekanan perifer, aktivitas saraf simpatik yang meningkat dan aktivitas renin plasma rendah yang berperan sebagai faktor natriuretik dan menyebabkan peningkatan reabsorbsi garam sehingga tidak terjadi peningkatan tekanan darah (Puspita, Nina, 2016).

Hipertensi kini menjadi masalah global karena prevalensinya yang terus meningkat dan diperkirakan pada tahun 2025, 29\% orang dewasa akan terkena hipertensi (Artiyaningrum, 2016). Berdasarkan Data Riset Kesehatan Dasar (Riskesdas tahun 2013) jumlah penderita hipertensi di Indonesia sebanyak $25.8 \%$. Jumlah penderita 
hipertensi di Kalimantan Barat sebesar 9.45\%. Di Singkawang jumlah penderita hipertensinya pada tahun 2016 sebesar $8.88 \%$, sedangkan penderita hipertensi yang tercatat di UPT. Puskesmas Singkawang Timur I tahun 2017 berjumlah 832 orang. Penelitian ini bertujuan untuk mengetahui hubungan asupan lemak, asupan garam dan status gizi terhadap tekanan darah pada penderita hipertensi di UPT. Puskesmas Singkawang Timur I (Dinas Kesehatan Kota Singkawang, 2016).

\section{METODE PENELITIAN}

Penelitian ini berlokasi di UPT Puskesmas Singkawang Timur I dengan waktu penelitian selama 1 bulan. Penelitian dilakukan dengan desain penelitian cross sectional secara kuantitatif. Sampel penelitian ini merupakan bagian dari populasi yang memenuhi kriteria inklusi dan eksklusi sejumlah 89 orang. Pengambilan sampel dilakukan dengan metode accidental sampling. Data dikumpulkan dengan menggunakan instrumen kuesioner, food recall $1 \times 24$ jam, timbangan injak dan microtoise. Data dianalisis dengan menggunakan metode Chi Square.

\section{HASIL PENELITIAN DAN \\ PEMBAHASAN \\ Gambaran Umum}

Kecamatan Singkawang Timur merupakan salah satu dari 5 kecamatan yang ada di Kota Singkawang. Terletak pada $0^{\circ} 45^{\prime} 17^{\prime \prime}$ 101'21,51" Lintang Utara dan 108'59'45,1" - 109¹0'19" Bujur Timur dengan luas wilayah 166,26 $\mathrm{Km}^{2}$. Dibandingkan dengan 4 Kecamatan lain di kota Singkawang, Kecamatan Singkawang Timur merupakan kecamatan terbesar kedua dari segi luas wilayah setelah Kecamatan Singkawang Selatan.

\section{Karakteristik Responden}

1) Umur

Tabel 1. Distribusi Penderita Hipertensi Berdasarkan Umur

\begin{tabular}{ccc}
\hline Umur & Jumlah $(\mathrm{N})$ & $\begin{array}{c}\text { Persentase } \\
(\%)\end{array}$ \\
\hline $39-50$ & 24 & 26.9 \\
\hline $51-60$ & 37 & 41.6 \\
\hline $61-81$ & 28 & 31.5 \\
\hline Total & 89 & 100
\end{tabular}

Sumber : Data Primer

Tabel 1 menunjukkan bahwa responden berada paling banyak di rentang umur 51-60 tahun, yaitu sebanyak 37 orang (41.6\%) dan paling sedikit berada di rentang umur 39-50 tahun, yaitu sebanyak 24 orang $(26.9 \%)$.

Seiring bertambahnya umur, maka arteri kehilangan elastisitasnya atau kelenturannya. $\mathrm{Hal}$ ini disebabkan oleh perubahan alami pada jantung, pembuluh darah, dan hormon. Arteri besar kehilangan kelenturannya dan menjadi kaku. Oleh karena itu darah setiap denyut jantung dipaksa untuk melalui pembuluh yang lebih sempit daripada biasanya dan menyebabkan naiknya tekanan darah. Apabila perubahan tersebut disertai faktorfaktor lain, maka bisa memicu terjadinya hipertensi (Menad, 2016).

2) Jenis Kelamin

Tabel 2. Distribusi Frekuensi Responden Berdasarkan Jenis Kelamin

\begin{tabular}{ccc}
\hline $\begin{array}{c}\text { Jenis } \\
\text { kelamin }\end{array}$ & $\begin{array}{c}\text { Jumlah } \\
(\mathrm{N})\end{array}$ & $\begin{array}{c}\text { Persentase } \\
(\%)\end{array}$ \\
\hline Laki-laki & 40 & 44.9 \\
\hline Perempuan & 49 & 55.1 \\
\hline Total & 89 & 100
\end{tabular}

Sumber : Data Primer

Dilihat dari jenis kelaminnya seperti terlihat pada Tabel 2, responden perempuan berjumlah 49 orang $(55.1 \%)$ dan laki-laki 40 orang $(44.9 \%)$.

Perempuan cenderung menderita hipertensi daripada lakilaki dan akan mengalami 
peningkatan resiko hipertensi setelah menopause, yaitu usia diatas 45 tahun. Perempuan yang belum menopause akan dilindungi oleh hormone Estrogen yang berperan dalam peningkatan kadar HDL. Kadar HDL yang tinggi merupakan pelindung dalam mencegah terjadinya proses aterosklerosis. Namun, pada masa premenopouse wanita mulai kehilangan hormon estrogen sehingga pada usia diatas 45 tahun prevalensi hipertensi pada wanita lebih tinggi (Novitaningtyas, 2014).

3) Tingkat Pendidikan

Tabel 3. Distribusi Frekuensi Responden Berdasarkan Pendidikan

\begin{tabular}{ccc}
\hline $\begin{array}{c}\text { Tingkat } \\
\text { Pendidikan }\end{array}$ & Jumlah (N) & $\begin{array}{c}\text { Persentase } \\
(\%)\end{array}$ \\
\hline SD & 21 & 23.6 \\
\hline SMP & 21 & 23.6 \\
\hline SMA & 39 & 43.8 \\
\hline $\begin{array}{c}\text { Perguruan } \\
\text { Tinggi }\end{array}$ & 8 & 9 \\
\hline Total & 89 & 100
\end{tabular}

Sumber : Data Primer

Tabel 3 diatas menunjukkan bahwa mayoritas pendidikan responden adalah SMA sebanyak 39 orang $(43.8 \%)$, dan yang palling sedikit adalah responden yang berpendidikan perguruan tinggi 8 orang $(9 \%)$.

Penyakit hipertensi cenderung tinggi pada penderita yang berpendidikan rendah dan menurun sesuai dengan peningkatan pendidikan. Hipertensi semata-mata tidak diakibatkan dengan perbedaan tingkat Pendidikan. Namun, tingkat pendidikan berpengaruh terhadap gaya hidup sehat dengan tidak merokok, tidak minum alkohol, dan lebih sering berolahraga. Tingginya resiko terkena hipertensi pada orang yang berpendidikan yang rendah kemungkinan disebabkan oleh kurangnya pengetahuan para responden yang berpendidikan rendah terhadap kesehatan dan sulit menerima informasi yang diberikan oleh petugas sehingga berdampak pada perilaku dan pola hidup sehat (Chasanah, Uswatun, Siti \& Syarifah, 2017).

4) Tingkat Pekerjaan

Tabel 4. Distrubusi Frekuensi Responden

\begin{tabular}{ccc}
\multicolumn{3}{c}{ Berdasarkan Jenis Pekerjaan } \\
\hline $\begin{array}{c}\text { Jenis } \\
\text { Pekerjaan }\end{array}$ & $\begin{array}{c}\text { Jumlah } \\
(\mathrm{N})\end{array}$ & $\begin{array}{c}\text { Persentase } \\
(\%)\end{array}$ \\
\hline $\begin{array}{c}\text { Tidak } \\
\text { Bekerja }\end{array}$ & 49 & 55.1 \\
\hline Bekerja & 41 & 44.9 \\
\hline Total & 89 & 100
\end{tabular}

Sumber :Data Primer

Seperti terlihat pada Tabel 4, responden yang tidak bekerja, 49 orang (55.1\%), lebih banyak daripada responden yang bekerja, 40 orang $(44.9 \%)$.

Orang yang tidak bekerja umumnya memiliki aktivitas fisik yang kurang baik daripada orang yang bekerja. Selain itu, tingkat stress dan bosan dari orang yang tidak bekerja dapat memicu kebiasaan hidup dan pola makan yang salah. Misalnya, mereka merokok, kurang berolahraga, juga mengkonsumsi alkohol (Kurnianingsih, 2016).

5) Asupan Lemak

Tabel 5. Distribusi Frekuensi Responden Berdasarkan Asupan Lemak

\begin{tabular}{ccc}
\hline $\begin{array}{c}\text { Asupan } \\
\text { Lemak }\end{array}$ & Jumlah $(\mathrm{N})$ & $\begin{array}{c}\text { Persentase } \\
(\%)\end{array}$ \\
\hline Tinggi & 66 & 74.2 \\
\hline Rendah & 23 & 25.8 \\
\hline Total & 89 & 100 \\
\hline
\end{tabular}

Sumber : Data Primer

Tabel 5 menunjukkan bahwa responden dengan asupan lemak tinggi sebanyak 66 orang (74.2\%), sedangkan responden dengan asupan lemak rendah sebanyak 23 orang (25.8\%).

Asupan lemak yang tinggi lebih sering mengkonsumsi makanan yang bersantan, jerohan, telur puyuh, dan makanan yang digoreng 
setiap harinya. Selain itu, juga mereka lebih sering mengkonsumsi makanan yang bersantan yang dipanasi berkali-kali dan makanan tersebut dikonsumsi lebih dari 1 hari (Hapsari, Aulia, 2018).

6) Asupan Garam

Tabel 6. Distribusi penderita Hipertensi berdasarkan Asupan Garam

\begin{tabular}{ccc}
\hline $\begin{array}{c}\text { Asupan } \\
\text { Garam }\end{array}$ & $\begin{array}{c}\text { Jumlah } \\
(\mathrm{N})\end{array}$ & $\begin{array}{c}\text { Persentase } \\
(\%)\end{array}$ \\
\hline Tinggi & 41 & 46.1 \\
\hline Rendah & 48 & 53.9 \\
\hline Total & 89 & 100
\end{tabular}

Sumber : Data Primer

Tabel 6 menunjukkan bahwa responden dengan asupan garam tinggi berjumlah 41 orang (46.1\%), dan responden dengan asupan garam rendah sebanyak 48 orang (53.9\%).

Garam jika dikonsumsi lebih banyak akan meretensi lebih banyak air untuk mempertahankan pengenceran elektolit, sehingga cairan intenstin bisa terakumulasi dan volume plasma dapat menyebabkan peningkatan tekanan darah, terutama apabila fleksibilitas pembuluh darah menurun oleh aterosklerosis (Darmawan, Hasbullah, 2018).

7) Status Gizi

Tabel 7

Distribusi Penderita Hipertensi Berdasarkan Status Gizi

\begin{tabular}{lcc}
\hline \multicolumn{1}{c}{ Status Gizi } & $\begin{array}{c}\text { Jumlah } \\
(\mathrm{N})\end{array}$ & $\begin{array}{c}\text { Persentase } \\
(\%)\end{array}$ \\
\hline Gizi Normal & 68 & 76.4 \\
$\geq 18.5-<24.9$ & & 23.6 \\
\hline $\begin{array}{l}\text { Berat Badan } \\
\text { Lebih } \geq 25.0\end{array}$ & 21 & \\
\hline Total & 89 & 100 \\
\hline
\end{tabular}

Sumber : Data Primer

Dapat dilihat pada Tabel 7, status gizi responden paling banyak adalah normal, yaitu sebanyak 68 orang (76.4\%), dan status gizi responden yang sedikit adalah berat badan lebih, yaitu sebanyak 21 orang (23.6\%).
Tubuh yang mengalami obesitas akan memerlukan oksigen lebih tinggi yang menyebabkan peningkatan kerja jantung. Selain itu, curah jantung dan sirkulasi volume darah tinggi, resistensi perifer berkurang atau normal, sedangkan aktivitas saraf simpatik meningkat dengan aktivitas renin plasma yang rendah. Orang yang kegemukan (berlemak) dan mengalami obesitas akan lebih mudah terkena hipertensi. Sebagian besar penderita hipertensi mengalami obesitas (Mulyati, 2011).

\section{Hasil Analisis Bivariat}

Analisis Bivariat menggunakan Uji Korelasi untuk mengetahui keeratan Hubungan Asupan Lemak, Asupan Garam dan Status Gizi terhadap Tekanan Darah pada Penderita Hipertensi. Hasil dari Analisis Bivariat tersebut dapat dilihat dalam tabel berikut:

1) Hubungan Antara Asupan Lemak dan Tekanan Darah Tabel 8

Hubungan Antara Asupan Lemak dan Tekanan Darah Di UPT. Puskesmas Singkawang Timur

\begin{tabular}{|c|c|c|c|c|c|}
\hline \multirow{3}{*}{$\begin{array}{l}\text { Asupan } \\
\text { Lemak }\end{array}$} & \multicolumn{4}{|c|}{ Tekanan Darah } & \multirow{6}{*}{$p=0.71$} \\
\hline & \multicolumn{2}{|c|}{ Tinggi } & \multicolumn{2}{|c|}{ Normal } & \\
\hline & $\mathrm{N}$ & $\%$ & $\mathrm{~N}$ & $\%$ & \\
\hline Tinggi & 57 & 78.1 & 9 & 56.25 & \\
\hline Rendah & 16 & 21.9 & 7 & 45.75 & \\
\hline Total & 73 & 100 & 16 & 100 & \\
\hline
\end{tabular}

Tabel 8 diatas menujukkan bahwa responden dengan asupan lemak tinggi memiliki tekanan darah berjumlah 57 orang (78.1\%) dan responden dengan tekanan darah normal sebanyak 9 orang $(21.9 \%)$. Selain itu, responden dengan asupan lemak rendah 
dan memiliki tekanan darah tinggi sebanyak 16 orang (21.9\%) dan yang bertekanan darah normal sebanyak 7 orang (45.75\%). Merujuk kepada hasil analisis yang menggunakan uji statistik dengan chi square, hasil uji statistiknya menunjukan $p$ value sebesar 0.71 dimana nilai $P$ lebih besar dari 0.05. Hasil tersebut menunjukan bahwa tidak adanya hubungan antara asupan lemak dengan tekanan darah di UPT. Puskesmas Singkawang Timur I.

Penelitian ini sejalan
dengan penelitian yang
dilakukan oleh Sarasaty di
Kelurahan Sawah Baru,
menunjukan tidak ada hubungan yang signifikan antara asupan lemak dengan tekanan darah dengan $p$ value 0.658 (Sarasaty, Rinawang, 2011).

Asupan lemak yang berlebih dapat menyebabkan peningkatan kadar kolesterol, LDL, dan trigliserida yang menumpuk pada dinding pembuluh darah dan akan membentuk plak (Widyaningrum, 2012).

Hal ini juga sejalan
dengan dilakukan oleh Ismuningsih tentang pengaruh konsumsi lemak terhadap tekanan darah penderita hipertensi rawat jalan di rumah sakit PKU Muhammadiyah Surakarta. Hasil didapat bahwa $p$ lebih besar dari 0.05 dimana nilai $p$ pada hasil penelitian adalah 0.150 , yang artinya tidak ada hubungan yang bermakna antara asupan lemak dengan tekanan darah pada penderita hipertensi (Ismuningsih, 2013).
2) Hubungan antara Asupan Garam dengan Tekanan Darah Tabel 9. Hubungan Asupan Garam Dengan Tekanan Darah di UPT. Puskesmas Singkawang Timur I

\begin{tabular}{|c|c|c|c|c|c|}
\hline \multicolumn{6}{|c|}{ Tekanan Darah } \\
\hline \multirow{2}{*}{$\begin{array}{c}\text { Asupan } \\
\text { Garam }\end{array}$} & \multicolumn{2}{|c|}{ Tinggi } & \multicolumn{2}{|c|}{ Normal } & \\
\hline & $\mathrm{N}$ & $\%$ & $\mathrm{~N}$ & $\%$ & \\
\hline Tinggi & 40 & 54.8 & 1 & 6.25 & $p=0.006$ \\
\hline Rendah & 33 & 45.2 & 15 & 93.75 & \\
\hline Total & 73 & 100 & 16 & 100 & \\
\hline
\end{tabular}

Sumber : Data Primer

Tabel 9 menunnjukkan bahwa responden dengan asupan garam tinggi yang memiliki tekanan darah berjumlah 40 orang (54.8\%) dan yang memiliki tekanan darah normal sebanyak 1 orang (6.25\%). Responden dengan asupan garam rendah yang memiliki tekanan darah tinggi sebanyak 33 orang (45.2\%) dan yang memiliki tekanan darah normal sebanyak 15 orang (93.75\%). Hasil analisis yang menggunakan uji statistik dengan chi square menunjukan bahwa $p$ value sebesar 0.00 ; nilainya lebih kecil dari 0.05 . Hasil tersebut menunjukan adanya hubungan antara asupan garam dengan tekanan darah di UPT. Puskesmas Singkawang Timur I. Penelitian ini sejalan dengan temuan penelitian yang dilakukan Widyaningrum dengan sampel lansia di kelurahan Makan Haji Kecamatan Kertasura. Dia melaporkan bahwa ada hubungan signifikan antara asupan natrium dengan tekanan darah dengan nilai $p$ adalah 0.006 dimana suatu korelasi dinyatakan berhubungan jika nilai p kurang dari 0.05 (Widyaningrum, 2012). 
Asupan garam yang tinggi akan menyebabkan pengeluaran yang berlebih dari hormon natriouretik yang secara tidak langsung akan meningkatkan tekanan darah (Wulandari, 2011). Hal ini sejalan dengan yang melaporkan bahwa ada hubungan yang bermakna antara asupan natrium dengan tekanan darah (Abdurrachim, 2016).

3) Hubungan Antara Status Gizi dengan Tekanan Darah

Tabel 10. Hubungan Antara Status Gizi dan Tekanan Darah Di UPT. Puskesmas Singkawang Timur I

\begin{tabular}{|c|c|c|c|c|c|}
\hline \multirow{3}{*}{$\begin{array}{c}\text { Status } \\
\text { Gizi }\end{array}$} & \multicolumn{4}{|c|}{ Tekanan Darah } & \\
\hline & \multicolumn{2}{|c|}{ Tinggi } & \multicolumn{2}{|c|}{ Normal } & \\
\hline & $\mathrm{N}$ & $\%$ & $\mathrm{~N}$ & $\%$ & \\
\hline $\begin{array}{l}\text { Gizi } \\
\text { Normal } \\
\geq 18.5- \\
24.9\end{array}$ & 56 & 76.72 & 12 & 75 & $\mathrm{p}=0.884$ \\
\hline $\begin{array}{l}\text { Berat } \\
\text { Badan } \\
\text { Lebih } \\
\geq 25.0\end{array}$ & 17 & 23.28 & 4 & 25 & \\
\hline Total & 73 & 100 & 16 & 100 & \\
\hline
\end{tabular}

Sumber : Data Primer

Tabel 10 menunjukkan bahwa responden dengan status gizi normal yang memiliki tekanan darah sebanyak 56 orang $(76.2 \%)$ dan yang memiliki tekanan darah normal 12 orang $(75 \%)$. Responden dengan status gizi berat badan lebih yang memiliki tekanan darah tinggi sebanyak 17 orang $(23.28 \%)$ dan yang memiliki tekanan darah normal sejumlah 4 orang (25\%). Merujuk kepada hasil analisis yang menggunakan uji statistik dengan chi square, $p$ value-nya sebesar 0.884 , dan nilainya lebih besar dari 0.05 . Hasil tersebut menunjukan tidak adanya hubungan antara status gizi dengan tekanan darah di UPT. Puskesmas Singkawang Timur I
Tahun 2018. Hal ini sejalan dengan penelitian yang dilakukan Arna yang melaporkan tidak adanya hubungan antara status gizi dengan tekanan darah dengan $p$ value sebesar 0.142 di Panti Werdha Dharma Bakti Surakarta (Arna, Rona, 2015). Hal ini menunjukkan bahwa status gizi tidak berpengaruh langsung terhadap kejadian hipertensi.

Hal ini sejalan dengan penelitian yang dilakukan oleh Mustamin yang menyatakan bahwa tidak terdapat hubungan yang bermakna antara status gizi dengan tekanan darah di Puskesmas Boji Baru Kabupaten Barru dengan nilai $p=0.858$ (Mustamin, 2010).

\section{KESIMPULAN}

Dari hasil penelitian, dapat diperoleh kesimpulan sebagai berikut :

1. Responden dengan umur 39-50 tahun sebanyak 24 orang (26.9\%), umur 51-60 tahun orang sebanyak 37 orang $(41.6 \%)$ dan umur $61-81$ tahun orang 28 orang (31.5\%).

2. Jumlah responden berjenis kelamin perempuan sebanyak 49 orang $(55.1 \%)$, lebih banyak daripada responden yang berjenis kelamin laki-laki, yaitu 40 orang (44.9).

3. Mayoritas berpendidikan SMA, 39 orang $(43.8 \%)$, responden yang berpendidikan perguruan tinggi adalah yang paling sedikit jumlahnya, yaitu 8 orang (9\%).

4. Responden yang tidak bekerja sebanyak 49 orang $(55.0 \%)$, lebih banyak daripada responden yang bekerja 40 orang $(44.9 \%)$.

5. Sebanyak 66 orang (74.2\%) yang memiliki asupan lemak tinggi lebih banyak daripada yang memiliki asupan lemak rendah, yaitu 23 orang (25.8\%).

6. Responden yang berasupan garam tinggi sebanyak 41 orang (46.1\%), dan yang berasupan garam rendah sebanyak 48 orang (53.9\%). 
7. Sebagian besar responden memiliki status gizi normal, yaitu 68 orang $(76.4 \%)$, sedangkan responden dengan status gizi berat badan lebih berjumlah 21 orang (23.6\%).

8. Tidak ada hubungan antara asupan lemak dengan tekanan darah di UPT. Puskesmas Singkawang Timur I Tahun 2018.

9. Adanya hubungan asupan garam dengan tekanan darah di UPT. Puskesmas Singkawang Timur I Tahun 2018.

10. Tidak ada hubungan antara status gizi dengan tekanan darah di UPT. Puskesmas Singkawang Timur I Tahun 2018.

\section{REKOMENDASI}

1. UPT. Puskesmas Singkawang Timur I perlu mengadakan penyuluhan secara intensif melalui media Posyandu atau media lainnya, baik online maupun tatap muka secara langsung untuk pengendalian tekanan darah pada semua kalangan mengenai masalah penyakit degeneratif.

2. Bagi Akademi Gizi SDM Singkawang.

Menjadi masukan bagi institusi pendidikan tinggi untuk menambah wawasan dan pengetahuan mahasiswa tentang penyakit yang sering terjadi di masyarakat yang diimplementasikan dalam materi perkuliahan.

3. Bagi Peneliti Selanjutnya,

Perhatikan dalam melakukan penelitian karena kondisi lansia yang tidak kondusif bisa menjadi kendala dan bisa mempengaruhi hasil penelitian serta dapat meneliti faktor-faktor yang dapat dikontrol antara lain asupan natrium, merokok, stress, obesitas, gaya hidup dan obat. Faktor-faktor yang dapat tidak dapat dikontrol antara lain usia, jenis kelamin, dan riwayat keluarga, serta adanya penyakit penyerta lain seperti diabetes, stroke, penyakit jantung koroner dan gagal ginjal.

\section{UCAPAN TERIMA KASIH}

Terima kasih penulis sampaikan kepada :

1. Sutendy Yunior Siregar, SE.MM selaku direktur Akademi Gizi SDM Singkawang yang selalu memberikan arahan serta dukungan atas selesainya artikel ini.

2. Kepala UPT. Puskesmas Singkawang Timur I beserta staff yang membantu selama proses penelitian.

3. Semua responden yang membantu dalam penyelesaian penelitian ini.

\section{DAFTAR PUSTAKA}

Abdurrachim, R., Hariyawati, Indah \& Suryani, Nani. 2016. Hubungan Asupan Natrium, Frekuensi dan Durasi Aktivitas Fisik Terhadap Tekanan Darah Lansia Di Panti Sosial Tresna Werdha Budi Sejahtera dan Bina Laras Budi Luhur Kota Banjar Baru Kalimantan Selatan. 39.

Arna, Rona, D. 2015. Hubungan Status Depresi dan Status Gizi dengan Tekanan Darah Pada Lansia Di Panti Wredha Dharma Bhakti Surakarta. Universitas Muhammadiyah Surakarta.

Artiyaningrum, B. 2016. Faktor-Faktor Yang Berhubungan Dengan Kejadian Hipertensi Tidak Terkendali Pada Penderita Yang Melakukan Pemeriksaan Rutin di Puskesmas Kedungmundu Kota Semarang Tahun 2016. Public Health Perspective Journal, 1(1), 12-20. 
Chasanah, Uswatun, Siti \& Syarifah, N. 2017. Hubungan Karakteristik Individu Penderita Hipertensi Dengan Derajat Hipertensi Di Puskesmas Depok II Sleman Yogyakarta. Jurnal Formil (Forum IImiah) Kesmas Respati, 2.

Darmawan, Hasbullah, D. 2018. Asupan Natrium dan Status Gizi Terhadap Tingkat Hipertensi Pada Pasien Rawat Jalan Di RSUD Kota Makassar. Media Gizi Pangan, 25, 7.

Dinas Kesehatan Kota Singkawang. 2016. Profil Dinas Kesehatan Kota Singkawang. Singkawang : Dinas Kesehatan Kota Singkawang.

Hapsari, Aulia, N. 2018. Hubungan Asupan Lemak dan Aktivitas Fisik dengan Tekanan DarahmPada Lansia Di Kelurahan Sondokan Surakarta. Universitas Muhammadiyah Surakarta.

Ismuningsih, R. 2013. Pengaruh Konsumsi Lemak Terhadap Tekanan Darah Di Rumah Sakit PKU Muhammadiyah Surakarta. Universitas Muhammadiyah Surakara, 10.

Kurnianingsih, D. 2016. Faktor Risiko Hipertensi Pada lbu Rumah Tangga Di Desa Pemali Kabupaten Bangka. In Departemen Gizi Masyarakat Fakultas Ekologi Manusia Institut Pertanian Bogor.

Menad, A. 2016. Hubungan Asupan Protein, Lemak, Kalium dan Magnesium Terhadap Tekanan Darah Lansia. Universitas Diponegoro Semarang, 20.

Mulyati. 2011. Hubungan Pola Konsumsi Natrium dan Kalium serta Aktivitas Fisik dengan
Kejadian Hipertensi pada Pasien Rawat Jalan di RSUP. Wahidin Sudirohusodo Makassar. Universitas Hasanuddin Makassar.

Mustamin. 2010. Asupan Natrium, Status Gizi dan Tekanan Darah Usia Lanjut. Media Gizi Pangan, IX.

Novitaningtyas, T. 2014. Hubungan Karakteristik (Umur, Jenis Kelamin, Tingkat Pendidikan) Dan Aktivitas Fisik Dengan Tekanan Darah Pada Lansia Di Kelurahan MakamHaji Kecamatan Kartasura Kabupaten Universitas Sukoharjo. Surakarta, 16.

Nuraini, B. 2012. Demographic and Health Survey 2012. Jakarta : BPS, BKKBN, Kemenkes and ICF International.

Puspita, Nina, A. 2016. Hubungan Asupan Lemak, Asupan Natrium dan Status Gizi Dengan Tekanan Darah Sistolik Pada Wanita Pra Lansia Di Pos Kesehatan Lansia Kelurahan Bojong Bata Kecamatan Pemalang Kabupaten Pemalang. Universitas Muhammadiyah Surakarta, 16.

Sarasaty, Rinawang, F. 2011. FaktorFaktor Yang Berhubungan Dengan Hipertensi Pasa Kelompok Lanjut Usia Di Kelurahan Sawah Baru Kecamatan Ciputat, Kota Tangerang Selatan. Program Studi Kesehatan Masyarakat Fakultas Kedokteran Dan IImu Kesehatan UIN Syarif Hidayatullah.

Widyaningrum. 2012. Hubungan antara Konsumsi Makanan dengan Kejadian Hipertensi pada Lansia. Program Studi Gizi Masyarakat 
Universitas Jember.

Wulandari, S. \&. Susilo. 2011. Cara Jitu Mengatasi Hipertensi. Jakarta : Penerbit Andi.

Yulistina, F. 2017. Korelasi Asupan Makanan, Stress, Dan Aktivitas Fisik Dengan Hipertensi Pada Usia Menopause. Unnes Journal of Public Health, 6, 8. 